DOI: https://doi.org/10.31933/dijemss.v3i1

Received: 14 September 2021, Revised: 14 October 2021, Publish: 27 October 2021

\begin{tabular}{|c|c|c|}
\hline DUNASTISTER & $\begin{array}{l}\text { DIJEMSS } \\
\text { DINASTI INTERNATIONAL JOURNAL } \\
\text { OF EDUCATION MANAGEMENT AND } \\
\text { SOCIAL SCIENCE }\end{array}$ & $\begin{array}{r}\text { https://dinastipub.org/DIJEMSS } \\
\text { editor@dinastipub.org } \\
08117401455 @\end{array}$ \\
\hline
\end{tabular}

\title{
THE INFLUENCE OF ORGANIZATIONAL CULTURE, WORK MOTIVATION, AND WORK DISCIPLINE ON EMPLOYEE PERFORMANCE
}

\author{
Silvia Ersa Rahmadania ${ }^{1}$, Anik Herminingsih ${ }^{2}$ \\ ${ }^{1}$ Mercu Buana University, Jakarta, Indonesia, silviaersa.ser@gmail.com \\ ${ }^{2}$ Mercu Buana University, Jakarta, Indonesia
}

Corresponding Author: Silvia Ersa Rahmadania

\begin{abstract}
This study aims to determine and analyze the influence of organizational culture , motivation to work, and work discipline t erhadap performance of employees at PT TJB . This research was conducted on 80 respondents who are permanent employees, data collection techniques using questionnaires. The research design used is causality . Data processing is done by analysis of Partial Least Square (Smart -PLS) version 3.0. The results of the study show that organizational culture dominated by the type of hierarchy, the most dominant work motivation is about the need for achievement or achievement and work discipline is about obedience to work rules. The results of hypothesis testing prove that organizational culture, work motivation and work discipline have a positive and significant effect on employee performance at PT TJB.
\end{abstract}

Keywords: Organizational Culture, Work Motivation, Work Discipline, and Performance.

\section{INTRODUCTION}

Businesses that are formed within an organization certainly need resources as capital, materials and machines. To operate an organization or company, of course, requires human resources, namely employees, without employees the company will not be able to operate properly in achieving the desired goals. PT TJB which is engaged as a heavy equipment transportation service company that operates in the Kalimantan area and has an office as a supervisory management that manages or controls all transactions starting from purchases and sales in the West Jakarta area. This company has been established since 2000, which can be said as a family company because the majority of the founders and shareholders in this company have ties or kinship relations. PT TJB operates in carrying out transportation services and owns vehicles in the form of trontons and excavators in the Kalimantan area, and has an office in the Jakarta area which is intended as management that manages, controls, controls, and makes and receives all data collection reports carried out by the Kalimantan office.

The development of the business world, the more consumer demand, the more problems faced by the company or the management. Companies are required to be able to work effectively in terms of completing work as desired by customers and efficiently, namely 
working using resources and energy that can adjust to needs. The level of public demand for services has a positive impact on PT TJB because of the large number of consumer demands. However, the request has not been able to be matched by the punctuality of completing the trip according to the specified schedule so that there is a delay in the completion process.

Realization data for 1 year concludes that the achievement of retention and tonnage still has not adjusted to the company's standardization. Even now, when the Covid - 19 pandemic in Indonesia has greatly impacted PT TJB, which originally had a lot of consumer demand, it has decreased, and requires the company to reduce employees and also close the Jakarta regional office so that it only employs employees in the Kalimantan area. In addition, the company also lowered the standardization of employee target achievement, but this has not yet had an impact on improving employee performance. Improved employee performance will bring progress for the company to be able to survive in an unstable competitive business environment. An effective or successful company if it is supported by quality human resources. On the other hand, companies that fail are due to 2 performance factors from unqualified human resources. So the performance of human resources is very influential on the success of a company without exception. According to Mangkunegara (2013) there are several factors that can affect performance, namely the ability factor and motivational factor.

According to Robbins and Judge (2017) organizational culture refers to a system of various meanings carried out by members that distinguishes the organization from other organizations. Organizational culture is a system of shared meanings shared by members that distinguishes an organization from other organizations. With the mistakes that have been made by employees in completing the work, of course, it has an impact on the survival or operations of the company that has been determined according to organizational standards. The company seeks to create employees who are ready to meet company targets in order to improve company operations and meet employee needs. To make employees a professional workforce, of course, not only by providing coaching or learning, but also by paying attention to other aspects such as: increasing discipline, providing motivation in the form of awards, providing incentives with a bonus system and so on in order to create enthusiasm or work motivation. Employees as the most important asset in an organization. Motivation has components, namely internal components and external components.

The internal component is a change in a person, a state of feeling dissatisfied, and psychological tension. The external component is what a person wants, the goal of which is the direction of his behavior. So, the internal components are some of the needs to be satisfied, while the external components are the goals to be achieved, if we look at the needs, motivations, actions or behavior of goals and satisfaction, there is a strong relationship and connection. Regarding the low level of employee discipline, it can be seen based on the level of absenteeism frequency. The higher the level of absenteeism, it will hinder the running of the company's operational system and or delay the completion of work, on the contrary if the level of absenteeism is low then the work discipline in the company will increase and not delay the completion of work. 
Basically an organization or company wants a high level of employee discipline so as to create rules or regulations that will shape the discipline of each individual employee it has. The profession as an employee has duties and is obliged to meet the needs of the company in accordance with the assigned tasks and work standards that have been determined. However, not a few employees feel uncomfortable with the regulations provided by the company. Fachreza of some previous studies, et al (2018) meny a Takan that un tuk improve organizational performance through the performance of employees, the factors that need to be considered seriously include employee motivation, organizational culture, work environment and others. This is because these factors can affect the performance, dedication, and loyalty and love of employees for their work and organization. So the organization must be able to create conditions that can encourage or enable employees to develop and improve their skills and abilities optimally. Based on previous research, employee performance can also be influenced by work discipline. According to Wales, Mandey \& Wenaas (2017), there is a significant influence between organizational culture, leadership style and work discipline, both simultaneously and partially, on employee performance. M enyatakan that the company was established to achieve the main objectives that have been agreed upon, then the company needs to have employees that perform well. To create good performance, it is necessary to have an organizational culture, work discipline and the right leadership style.

Based on the background and several phenomena that exist at PT TJB, it is feared that it can have an impact on daily work activities so that the work results are less than optimal, the researchers are interested in conducting research with the title "The Influence of Organizational Culture, Work Motivation, and Work Discipline on Employee Performance At PT TJB".

\section{LITERATURE REVIEW}

\section{Definition of Organizational Culture}

According to Cameron and Quinn (2011) present organizational culture as "how things are around here " where this reflects the prevailing ideology, which people carry in their heads . According to Robbins and Coulter (2015) organizational culture is a set of values, principles, traditions, and ways of working that are shared by and influence the behavior and actions of organizational members. Meanwhile, according to sociology in Herminingsih (2014) culture is translated as a collection of symbols, myths, and rituals that are important in understanding a social reality. The approach used by sociology is more about the attitude of a certain group of people or communities in dealing with and responding to various phenomena that occur around them. Understanding organizational culture, experts' understanding of organizational culture as a shared agreement about the values of life that increases all understanding of people in organizations underlies the importance of understanding organizational culture underpinning the people who are members of it. Cameron \& Ettington in Cameron and Quinn (2011) culture is a socially constructed organizational attribute that functions as a social glue that holds organizations together. 
Based on the definitions above, it can be concluded that organizational culture is a value system that is obtained and developed by the organization and the pattern of habits and basic philosophy of its founder, which is formed into rules that are used as guidelines for thinking and acting in achieving organizational goals. A culture that grows strong is able to spur the organization towards better development.

\section{Definition of Work Motivation}

According to Hasibuan (2017) work motivation comes from work enthusiasm and a person's movement power so that they can work together, work effectively and be integrated with all their efforts to achieve satisfaction. According to Robbins and Judge (2017) motivation is a process that describes a person's strength, direction, and persistence in an effort to achieve goals. Since motivation in general is related to efforts towards each goal, we will narrow the focus to organizational goals on work-related behavior. Without the motivation of employees to work together for the benefit of the company, the goals that have been set will not be achieved. Conversely, if there is high motivation from employees, then this is a guarantee for the company's success in achieving its goals. Motivation is defined by Mangkunegara (2014) that "Motivation as an energizing condition of the organism that serves to direct that organism toward the goal of a certain class" (Motivation as a condition that moves humans towards a certain goal). According to Robbins and Coulter (2016) motivation is the process by which one's efforts are energized, directed, and sustained towards the achievement of a goal. Based on the above definition, it can be concluded that motivating employees is one of the most important and most challenging aspects of management. Motivation is not just about working hard motivation also reflect the viewpoint of someone me $\mathrm{n}$ genai ability of one's own. Try to assess yourself about the confidence in the ability to achieve success.

\section{Definition of Work Discipline}

According to Rivai (2014) work discipline is a tool used by managers to communicate with employees so that they are willing to change a behavior as well as an effort to increase one's awareness and willingness to obey all company regulations and applicable social norms. Basically, every agency or organization wants a high level of employee discipline. According to Sutrisno (2015) work discipline shows the condition or attitude of respect that exists in employees towards company rules and regulations. Thus, if the regulations or provisions in the company are ignored or often violated, the employee has poor work discipline. Discipline itself is defined as the willingness of someone who arises with his own awareness to follow the rules that apply in the organization. Handoko (2011), states that discipline is a management activity to implement organizational standards . Based on the above definition, it can be concluded that high work discipline must always be maintained, and even improved for the better. Good discipline reflects a person's sense of responsibility for the tasks assigned to him. This can encourage the emergence of morale and the achievement of company, employee and community goals. Therefore, every leader always tries to make his subordinates have good discipline.

\section{Definition of Employee Performance}


According to Gomes (2010), employee performance as expressions such as output, efficiency and effectiveness are often associated with productivity. Performance is a general term used for part or all of the actions or activities of an organization over a period with reference to a number of standards such as past or projected costs, on the basis of efficiency, accountability or management accountability and the like (Gaol, 2015). Employee performance (work achievement) is the result of work in quality and quantity achieved by an employee in carrying out his duties in accordance with the responsibilities given to him (Mangkunegara, 2013). According to Sedarmayanti (2011) performance is the result of work that can be achieved by a person or group of people in an organization in accordance with their respective authorities and responsibilities in an effort to achieve organizational goals. From the definition according to the experts above, it can be concluded that employee performance is one of the dimensions that can be used to measure, evaluate the strength and discipline of employees in surviving and carrying out their duties and obligations to the organization in which they are sheltered.

\section{RESEARCH METHODS}

This research article uses quantitative methods with associative problem formulation. According to Sugiyono (2016) quantitative research can be interpreted as a research method based on the philosophy of positivism, used to examine certain populations or samples, data collection using research instruments, data analysis is quantitative or statistical, with the aim of testing predetermined hypotheses while problem formulation associative research is a study that aims to determine the relationship between two or more variables (Sugiyono, 2016). Based on the title taken by the author, namely "the influence of organizational culture, work motivation, and work discipline on employee performance at PT TJB". Thus, the authors identify each variable and make operational variables.

$\mathrm{X}_{1}=$ Organizational Culture

According to Cameron and Quinn (2011) present organizational culture as "how things are around here" where it reflects the prevailing ideology, which people carry in their heads.

$\mathrm{X}_{2}=$ Work Motivation

According to Hasibuan (2017) work motivation comes from work enthusiasm and one's movement power so that they can work together, work effectively and be integrated with all their efforts to achieve satisfaction.

$\mathrm{X}_{3}=$ Work Discipline

According to Rivai (2014) work discipline is a tool used by managers to communicate with employees so that they are willing to change a behavior as well as an effort to increase one's awareness and willingness to obey all company regulations and applicable social norms.

$\mathrm{Y}=$ Employee Performance

According to Gomes (2010), employee performance as expressions such as output, efficiency and effectiveness are often associated with productivity.

\section{FINDINGS AND DISCUSSION}

Company Profile 
PT TJB which is engaged as a heavy equipment transportation service company operating in the Kalimantan area and has an office as a supervisory management that manages or controls all transactions starting from buying and selling in the West Jakarta area. This company has been established since 2000 , which can be said as a family company because the majority of the founders and shareholders in this company have ties or kinship relations. PT TJB operates to run transportation services and owns vehicles in the form of trontons and excavators in the Kalimantan area, and has an office in the Jakarta area which is intended as management that manages, controls, controls, and makes and receives all data collection reports conducted at the Kalimantan office.

\section{Vision and Mission PT. TJB \\ Vision}

Becoming a company that can act and provide policy values that are consistent with the company's business ethics with professionalism in mastering the work undertaken, as well as ensuring safety by minimizing risks so that accidents do not occur in order to protect company assets from possible losses.

\section{Mission}

1) Providing leading and well-known transportation services, is an excellent service and providing services according to quality standards according to expectations and even exceeding expectations.

2) Providing leading company solutions, is an effort to provide total services so that it is always a customer solution and can increase work productivity..

3) Creating services that can be enjoyed and met by customers in the territory of Indonesia so that the company can further expand its business network.

4) Marketing the range of quality services according to standards for customers in various regions by developing business networks using regional expansion.

5) Maintain and improve the services provided to customers by controlling the cost of service.

\section{Result of Research Description \\ Characteristics of Respondents}

Descriptive profile of respondents is the identity of respondents who provide an interpretation of the objectivity of research on the influence of organizational culture, work motivation, and work discipline on employee performance at PT TJB. The description of the respondent's profile is divided into 4 parts, namely according to: age, gender, education level, and status. Based on $u$ it can be seen that the age of the majority of employees at PT TJB is ranged in age from 21-30 with a percentage of 34\%, employees at PT TJB an employee youthful which still has passion and still have a lot of desire also of interest in the work. The characteristics of respondents by sex can be seen that the gender of employees at PT TJB is dominated by men as much as 43 people with a percentage of $54 \%$. This is because the work in the field of heavy equipment rental services tends to require certain manpower and expertise. While the characteristics of respondents based on their final education, it can be seen that the majority of employees at PT TJB have a final education of SMK as many as 60 people with a percentage of $75 \%$. This is because the PT TJB company is not too concerned with education 
but prioritizes expertise and experience. Karakteristik respondents by status can be seen that the majority of employees at PT TJB had been "married" as many as 56 people with a percentage of $56 \%$. Married employees tend to need free time to gather with family. The characteristics of respondents by job title, the majority of employees at PT TJB is a caretaker of heavy equipment, namely a number of 49 is equivalent to $61 \%$ of respondents as the team management as many as 25 people with a percentage of $31 \%$, and at least a team of finance with the number of respondents 6 , equivalent to $8 \%$.

\section{Variable Descriptive Analysis}

The instrument for organizational culture that has the highest mean/average value is found in the hierarchy culture type, which is 4.00 . So it can be seen that respondents' perceptions of the company's organizational culture is an organizational culture that has the following characteristics: clarity in decision-making authority, standardized rules and procedures and strict control functions. While the lowest mean/average value is found in the clan culture type, which is 3.95 , which means that the average respondent's perception does not agree that the company has an organizational culture that views that the environment can be managed well through cooperation and employee development, customers are partners. Meanwhile, the instrument for work motivation which has the highest mean/average value is found in the dimension of the need for achievement or achievement, which is 4.28. Meanwhile, the lowest mean/average value is found in the need for affiliation, which is 4.09 . For work discipline instruments that have the highest mean/average value, the attendance dimension is 4.35. Meanwhile, the lowest mean/average value is found in the dimension of obedience to work regulations, which is 4.11 . Then the instrument for employee performance which has the highest mean/average value is found in the Quality of work dimension, which is 3.92. Meanwhile, the lowest mean/average value is found in the Initiative dimension, which is only 3.45 .

\section{Convergent Validity Test}

According to Ghozali (2015), convergent validity is related to the principle that the variables (manifest variables) of a construct should be highly correlated. Testing the Convergent Validity of the measurement model with reflexive indicators is assessed based on the correlation between the item score/component score and the construct store which is calculated by PLS. Individual indicators are considered valid if they have a correlation value above 0.70 . 


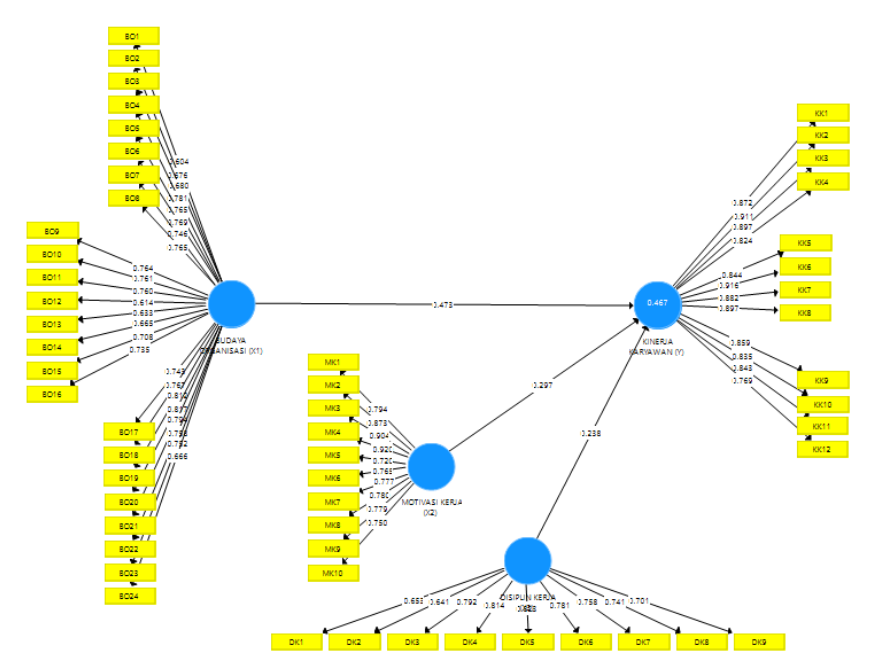

The results of the modification of the convergent validity test can be seen that all indicators have met the convergent validity because they have a factor loading value above 0.70 .

\section{Discriminant Validity Test}

Indicators of organizational culture have a higher cross loading value on organizational culture variables than on work discipline variables, employee performance and work motivation. The correlation of the work discipline variable with the indicator is higher on the work discipline variable than on the employee performance variable and work motivation. Then the overall employee performance indicators with a greater cross loading value on the employee performance variable than on the work motivation variable. Based on the results obtained, it can be stated that the indicators used in this study have good discriminant validity in compiling their respective variables. Another method to see discriminant validity is to look at the value of the square root of average variance extracted (AVE) of each construct with a correlation between the construct and other constructs in the model, then it is said to have a good discriminant validity value..

Table of Average Variance Extracted (AVE) Test Results

\begin{tabular}{|l|c|}
\hline Variable & Average Varince Extracted (AVE) \\
\hline Organizational culture $\left(\mathrm{X}_{1}\right)$ & 0,538 \\
\hline Work Discipline $\left(\mathrm{X}_{3}\right)$ & 0,559 \\
\hline Employee performance $(\mathrm{Y})$ & 0,746 \\
\hline Work motivation $\left(\mathrm{X}_{2}\right)$ & 0,654 \\
\hline
\end{tabular}

Source: Output PLS, 2021

From the table above, it can be seen that the AVE value of the organizational culture, work motivation, work discipline, and employee performance variables is greater than 0.5 , thus it can be stated that each variable has good discriminant validity.

Table of Discriminant Validity Test Results (Fornell-Lacker Criterium)

\begin{tabular}{|l|l|c|c|c|}
\hline & $\begin{array}{l}\text { Budaya Organisasi } \\
\left(\mathrm{X}_{1}\right)\end{array}$ & $\begin{array}{c}\text { Disiplin } \\
\text { Kerja }\left(\mathrm{X}_{2}\right)\end{array}$ & $\begin{array}{c}\text { Kinerja Karyawan } \\
(\mathrm{Y})\end{array}$ & $\begin{array}{c}\text { Motivasi } \\
\text { Kerja }\left(\mathrm{X}_{3}\right)\end{array}$ \\
\hline
\end{tabular}




\begin{tabular}{|l|c|c|c|c|}
\hline $\begin{array}{l}\text { Organizational } \\
\text { culture }\left(\mathrm{X}_{1}\right)\end{array}$ & 0,733 & & & \\
\hline $\begin{array}{l}\text { Work Discipline } \\
\left(\mathrm{X}_{3}\right)\end{array}$ & 0,185 & 0,747 & & \\
\hline $\begin{array}{l}\text { Employee } \\
\text { performance }(\mathrm{Y})\end{array}$ & 0,514 & 0,453 & 0,863 & \\
\hline $\begin{array}{l}\text { Work motivation } \\
\left(\mathrm{X}_{2}\right)\end{array}$ & $-0,013$ & 0,427 & 0,392 & 0,809 \\
\hline
\end{tabular}

Source: Output PLS, 2021

It is concluded that the square root of the average variance extracted ( $\sqrt{ } \mathrm{AVE})$ for each construct is greater than the correlation between one construct and the other constructs in the model. From the AVE value, the construct in the estimated model meets the discriminant validity criteria.

\section{Composite Reliability Test Results and Cronbach's Alpha}

If all values of latent variables have composite reliability and Cronbach's alpha values greater than 0.7 , it means that the construct has good reliability or the questionnaire used as a tool in this study is reliable or consistent.

Table of Composite Reliability Test Results and Cronbach's Alpha

\begin{tabular}{|l|c|c|c|}
\hline \multicolumn{1}{|c|}{ Variable } & Cronbach's Alpha & $\begin{array}{c}\text { Composite } \\
\text { Reliability }\end{array}$ & Description \\
\hline Organizational culture $\left(\mathrm{X}_{1}\right)$ & 0,962 & 0,965 & Reliabel \\
\hline Work Discipline $\left(\mathrm{X}_{3}\right)$ & 0,901 & 0,919 & Reliabel \\
\hline Employee performance $(\mathrm{Y})$ & 0,969 & 0,972 & Reliabel \\
\hline Work motivation $\left(\mathrm{X}_{2}\right)$ & 0,946 & 0,949 & Reliabel \\
\hline
\end{tabular}

Source: Output PLS, 2021

From the table above, it can be seen that the results of testing composite reliability and Cronbach's alpha show a satisfactory value, because all latent variables have composite reliability values and Cronbach's alpha is greater than 0.70 . This means that all latent variables are said to be reliable.

\section{Structural Model Testing Results (Inner Model)}

Inner model testing is the development of concept and theory-based models in order to analyze the relationship between exogenous and endogenous variables that have been described in a conceptual framework. The steps for testing the structural model (inner model) are as follows:

\section{R-Square Value Testing}

Looking at the R-square value which is the goodness-fit test of the model.

\begin{tabular}{|l|c|c|}
\hline \multicolumn{2}{|c|}{ Value table $^{\mathbf{2}}$} \\
\hline Variabel Endogen & R-square & R-square Adjusted \\
\hline Employee performance & 0,467 & 0,446 \\
\hline
\end{tabular}

Source: Output PLS, 2021 
From these data it can be concluded that the R-square value of 0,467 means that the model has a good level of goodness of fit model, which means the employee performance variable $(\mathrm{KK})$ which can be explained by the variables in the model, namely organizational culture, work motivation, and work discipline. $46,7 \%$, while $53,3 \%$ is explained by other variables not examined in this model.

\section{Goodness of Fit Model Test Results}

Goodness of Fit Testing The structural model on the inner model uses the predictiverelevance value $\left(\mathrm{Q}^{2}\right)$. Q-square value greater than 0 (zero) indicates that the model has predictive relevance. The R-square value of each endogenous variable in this study can be seen in the following calculations:

The predictive relevance value is obtained by the formula:

$Q^{2}=1-(1-R 1)\left(1-R_{p}\right)$

$Q^{2}=1-(1-0,467)$

$Q^{2}=1-(0,533)$

$Q^{2}=0,467$

The results of the above calculation show the predictive-relevance value of 0,467 which is greater than 0 (zero). This means that $46,7 \%$ of the variation in the employee performance variable (the dependent variable) is explained by the independent variable used. Thus the model is said to be feasible to have relevant predictive value.

\section{Hypothesis Testing Results (Estimated Path Coefficient)}

The significance value of this hypothesis can be obtained by the boostrapping procedure. Seeing the significance of the hypothesis by looking at the parameter coefficient values and the $t$-statistical significance value in the boostrapping report algorithm. To find out whether it is significant or not, it can be seen from ttable at alpha $0,05(5 \%)=1,96$, then $t_{\text {table }}$ dibandingkan dengan $t_{\text {count }}\left(t_{\text {statistics }}\right)$.

Table of Hypothesis Testing Results

\begin{tabular}{|l|c|c|c|c|l|}
\hline & $\begin{array}{c}\text { Original } \\
\text { Sample }\end{array}$ & $\begin{array}{c}\text { Standard } \\
\text { Deviation }\end{array}$ & t Statistics & $\boldsymbol{\rho}$ value & Description \\
\hline $\begin{array}{l}\text { Organizational culture } \rightarrow \\
\text { Employee performance }\end{array}$ & 0,473 & 0,113 & 4,205 & 0,000 & $\begin{array}{l}\text { Positive - } \\
\text { Significant }\end{array}$ \\
\hline $\begin{array}{l}\text { Work Discipline }\left(\mathrm{X}_{3}\right) \rightarrow \\
\text { Employee performance } \\
(Y)\end{array}$ & 0,283 & 0,096 & 2,474 & 0,015 & $\begin{array}{l}\text { Positive - } \\
\text { Significant }\end{array}$ \\
\hline $\begin{array}{l}\text { Work motivation }\left(\mathrm{X}_{2}\right) \rightarrow \\
\text { Employee performance } \\
(Y)\end{array}$ & 0,297 & 0,117 & 2,532 & 0,013 & $\begin{array}{l}\text { Positive - } \\
\text { Significant }\end{array}$ \\
\hline
\end{tabular}

Source: Output PLS, 2021 


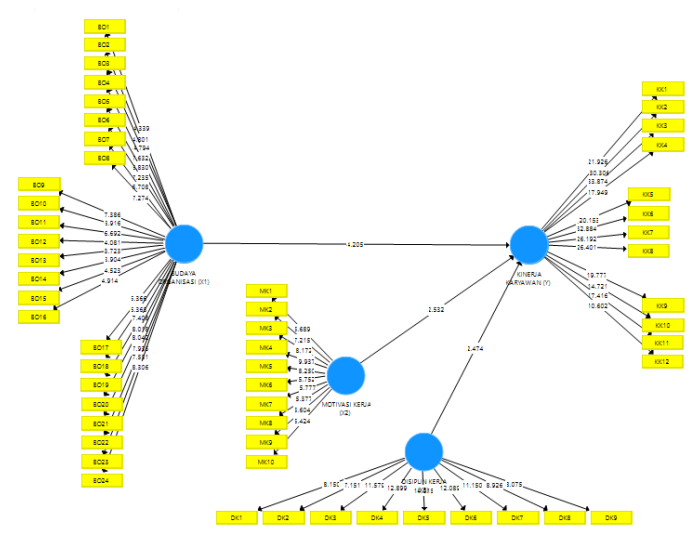

\section{Test Results Image Bootstrapping}

Source: Output PLS, 2021

Based on the tables and pictures of hypothesis testing, information to answer the hypothesis can be found with the following details:

1) Hypothesis 1 in this study is organizational culture has a positive and significant effect on employee performance. Based on Table 4.13 it is found that the value of $t$ statistics is greater than $t_{\text {table }}(4,205$ lebih besar dari 1,96). In addition, the determination of significance can also be determined by comparing the $\rho$-value with the level of uncertainty. The results of hypothesis testing can be seen that the organizational culture variable has a value of 0,000 . It means that the $\rho$-value is greater than $(\alpha) 0,05$, then the hypothesis is accepted. This shows that organizational culture has an effect on employee performance.

2) Hypothesis 2 in this study is that work motivation has a positive and significant effect on employee performance. Based on Table 4.13, it is found that the value of $t_{\text {statistic }}$ is greater than $t_{\text {tabel }}(2,474$ greater than 1,96), and the hypothesis is accepted. In addition, the determination of significance can also be determined by comparing the $\rho$-value with the level of uncertainty. The results of hypothesis testing can be seen, that the work motivation variable has a value of 0,015 . It means that $\rho$-value is smaller than alpha $(\alpha)$ 0,05 , then the hypothesis is accepted. This shows that work motivation has an effect on employee performance.

3) Hypothesis 3 in this study is that work discipline has a positive and significant effect on employee performance. Based on Table 4.13 it is found that the value of, $t_{\text {statistic }}$ is greater than $t$ tabel $(2,532$ is greater than 1,96), and the hypothesis is accepted. In addition, the determination of significance can also be determined by comparing the $\rho$-value with the level of uncertainty. The results of hypothesis testing can be seen, that the work compensation variable has a value of 0,013 . It means that $\rho$-value is smaller than alpha $(\alpha)$ 0,05 , then the hypothesis is accepted. This shows that work discipline has an effect on employee performance.

\section{DISCUSSION}

\section{The Influence of Organizational Culture on Employee Performance}

The influence of organizational culture on employee performance is described in Hypothesis 1 (H1), the results show Hypothesis 1 (H1) is accepted and means that organizational culture variables have a positive and significant influence on employee 
performance. That is, the deeper the organizational culture is accumulated or absorbed in the employees, the higher the performance produced by employees will be. If the level of organizational culture cannot be accumulated or absorbed in employees, it will also affect the resulting performance. The results of this study are relevant to the previous research proposed by Ghassani, et al (2020), Sulila \& Naue (2020) found that organizational culture and work discipline have a positive and significant effect on performance. Hasan (2017) in his research found that organizational culture has an effect on employee performance. In this study, the indicator that has the highest loading factor value is BO20 of 0.817 . This is in line with Cameron \& Ettington's theory in Cameron and Quinn (2011) that culture is a socially constructed organizational attribute that functions as a social glue that holds organizations together.

\section{The Effect of Work Motivation on Employee Performance}

The effect of work motivation on employee performance is described in Hypothesis 2 (H2), the results show that Hypothesis 2 (H2) is accepted and means that the work motivation variable has a positive and significant influence on employee performance. That is, the higher the level of work motivation felt by employees, the higher the performance produced by employees. If the level of work motivation felt by employees is low, it will also affect the resulting performance. The results of this study are relevant to the previous research proposed by Nuryasman \& Suryaman (2018), Mokodompit, et al (2016), besides Aima, et al (2017) which stated that motivation had a positive and significant effect on performance. In this study, the indicator that has the highest loading factor value is MK4 of 0,920. This is in line with the theory According to Robbins and Coulter (2016) motivation is a process in which a person's efforts are energized, directed, and sustainable towards achieving a goal.

\section{The Effect of Work Discipline on Employee Performance}

The effect of work discipline on employee performance is explained in Hypothesis 3 (H3), the results show Hypothesis 3 (H3) is accepted and means that the work discipline variable has a positive and significant influence on employee performance. That is, the higher the work discipline provided and applied by the company, the higher the level of performance produced. If the level of discipline given and applied by employees is low, it will also affect the resulting performance will decrease. The results of this study are relevant to the previous research proposed by Agussalim (2017), Razak, et al (2018), besides Santoso (2018) which shows that work discipline has a positive and significant effect on employee performance. In this study, the indicator that has the highest loading factor value is DK5 of 0.823 . This is in line with the theory. According to Sutrisno (2015) work discipline shows the condition or attitude of respect that exists in employees towards company rules and regulations.

\section{CONCLUSION AND SUGESTION CONCLUSION}

This study tries to analyze the variables related to the influence of organizational culture, work motivation and work discipline on employee performance at PT TJB. From the research results that have been obtained from the calculation of data processing using Partial Least Square (PLS) with the smartPLS 3.0, the following conclusions can be drawn: 
1. Organizational culture has a positive and significant influence on employee performance at PT TJB.

2. Work motivation has a positive and significant effect on employee performance at PT TJB.

3. Work discipline has a positive and significant effect on employee performance at PT TJB.

\section{SUGESTION}

Based on several research results and discussions as well as the conclusions that have been described previously, then some suggestions to be input for PT TJB and for further research, as for the suggestions that the author wants to recommend are as follows:

1. Based on the results of hypothesis testing regarding organizational culture, it was found that the BO1 indicator with the statement "The company is a very close place like a big family. The employees share in many ways" has the lowest loading factor value, which means that the majority of employees at PT TJB do not agree with the statement. It is suggested that companies need to apply a clan-type culture which has the main characteristic that the relationship between organizations is based on a sense of kinship, togetherness and carries a high spirit of loyalty.

2. Based on the results of hypothesis testing regarding work motivation, it was found that the MK10 indicator with the statement "I am able to complete work together with coworkers" has the lowest loading factor value, which means that the majority of employees at PT TJB do not agree with the statement. So it is necessary to increase motivation so that employee performance can also be improved.

3. Based on the results of hypothesis testing regarding work discipline, it was found that the DK2 indicator with the statement "I prioritize work over personal interests while at work" has the lowest loading factor value, which means that the majority of employees at PT TJB do not agree with the statement. So it is necessary to increase discipline to be able to reduce perceived conflicts in order to improve compliance with work regulations and can improve employee performance.

4. For further researchers who are interested in examining this topic in more depth, the authors suggest that further research can better evaluate the questions contained in the questionnaire so that they can accurately represent the variables to be measured. Further research is also expected to be able to look for other indicators as a measuring tool for the variables to be studied.

\section{BIBLIOGRAPHY}

Agussalim. (2017). Analysis Work Discipline and Work Spirit to Achievement Employees PT. Japfa Comfeed Indonesia Tbk. Wood Planting. Saudi Journal of Business and Management Studies, 2 (3), 286-296.

Aima, H., Adam, R., \& Ali, H. (2017). Model of Employee Performance: Competence Analysis and Motivation (Case Study at PT. Bank Bukopin, Tbk Center). Journal of Research in Business and Management, 4 (1), 49-59.

Arikunto, S. (2010). Prosedur Penelitian Suatu Pendekatan Praktek. Jakarta: Rineka Cipta. 
Astarman. (2019). Pengaruh Budaya Organisasi Dan Motivasi Kerja Terhadap Disiplin Kerja Pegawai Pada Perusahaan Daerah Kabupaten Indragiri Hulu. Jurnal Manajemen dan Bisnis, 8 (1), 119-127.

Cameron, K. S., \& Quinn, R. E. (2011). Diagnosing and Changing Organizational Culture, Third Edition. San Fransisco: CA : Jossey - Bass. David, Fred.

Dessler, G. (2015). Manajemen Sumber Daya Manusia Human Resource. Jakarta: Salemba Empat.

Elmi, F. (2018). Telisik Manajemen Sumber Daya Manusia. Jakarta: Mitra Wacana Media.

Fachreza, Musnandi, S., \& Majid, M. A. (2018). Pengaruh Motivasi Kerja, Lingkungan Kerja,

Dan Budaya Organisasi Terhadap Kinerja Karyawan Dan Dampaknya Pada Kinerja

Bank Aceh Syariah Di Kota Banda Aceh. Jurnal Magister ManajemenFakultas Ekonomi dan Bisnis Unsyiah, 2 (1), 115-122.

Ferdinand, A. (2014). Metode Penelitian Manajemen. Semarang: Badan Penerbit Universitas Diponegoro.

Gaol, C. J. (2015). A To Z Human Capital Manajemen Sumber Daya Manusia. Jakarta: PT.Grasindo Anggota Ikapi.

Ghassani, A. P., Radianto, W. E., \& Mastan, S. (2020). The Effect Of Organizational Culture, Motivation, And Self-Leadership On Student Performance In Start-Ups. Indonesian Journal of Business and Entrepreneurship by Ministry, 6 (2), 157-162 .

Ghozali, I. (2015). Aplikasi Analisis Multivariate dengan Program IBM SPSS.23. Semarang: Universitas Diponegoro.

Gomes, F. C. (2010). Manajemen Sumber Daya Manusia. Yogyakarta: Andi Offset.

Handoko, T. H. (2011). Manajemen Personalia \& Sumberdaya Manusia. Yogyakarta: BPFG UGM .

Hartono, B. D., \& Zubaidah. (2017). The Influence Of Leadership, Organizational Culture And Work Discipline On Teacher Performance Regarding Work Motivation As Interverning Variable (A Case Study Of Yayasan Pendidikan Pondok Pesantren Al Kholidin). International Journal of Economics, Business and Management Research, 1 (1), 69-95.

Hasan, S. (2017). Pengaruh Budaya Organisasi Terhadap kinerja Pegawai Bank BJB Cabang Banjarmasin. Jurnal Ilmiah Ekonomi Bisnis, 3 (2), 238-242.

Hasibuan, M. (2012). Manajemen Sumber Daya Manusia. Jakarta: PT Bumi Aksara.

Hasibuan, M. S. (2017). Manajemen Sumber Daya Manusia (Edisi Revisi). Jakarta: Bumi Aksara.

Herminingsih, A. (2014). Budaya Organisasi. Yogyakarta: CV Andi Offset.

Jufrizen. (2017). Efek Moderasi Etika Kerja Pada Pengaruh Kepemimpinan Transformasional dan Budaya Organisasi Terhadap Kinerja Karyawan. Jurnal Ekonomi Manajemen dan Bisnis, 18 (2), 145-158.

Kasim, D., Rantetampang, A., \& Lumbantobing, H. (2016). Relationships of Work Discipline, Leadership, Training, and Motivation to Performance of Employees Administration Abepura Hospital Papua 2015. International Journal of Sciences: Basic and Applied Research, 26 (1), 154-164.

Kempa, R., \& Luturmas, H. E. (2016). Leadership Behavior, Organizational Culture, and Teacher Performance. International Journal of Science and Research, 5 (10), 552-555. 
Kumajas, A. H., Lengkong, V. K., \& Wenas, R. (2016). Pengaruh Budaya Organisasi, Disiplin Kerja Dan Lingkungan Kerja Terhadap KInerja Karyawan Pada PT.PLN (Persero) Kantor Wilayah Suluttenggo. Jurnal EMBA, 4 (4), 1200-1208.

Mangkunegara, A. (2014). Manajemen Sumber Daya Manusia Perusahaan. Bandung: PT. Remaja Rosdakarya.

Mangkunegara, A. A. (2013). Manajemen Sumber Daya Manusia. Bandung: PT. Remaja Rosdakarya.

Mangkunegara, A. P. (2016). Manajemen Sumber Daya Manusia Perusahaan. Bandung: PT. Remaja Rosdakarya.

Mathis, R. L., \& Jackson, J. H. (2012). Manajemen Sumber Daya Manusia, Edisi Pertama. Jakarta: Salemba Empat.

Mokodompit, M. Z., Pangemanan, S. S., \& Pandowo, M. (2016). Influence Of Leadership Style, Work Motivation And Discipline On Employees Performance Cv Sumber Rejeki. Jurnal Berkala Ilmiah Efisiensi, 16 (4), 520-531.

Nuryasman, \& Suryawan, E. A. (2018). The Influence of Organizational Culture and Work Motivation Toward Employee Performance (Case Study On Employees of PT Inoac Polytechno Indonesia). Jurnal Manajemen, 12 (1), 74-90.

Pawirosumarto, S., Sarjana, P. K., \& Gunawan, R. (2016). The Effect Of Work Environtment, Leadership Style, And Organizational Culture Towards Job Statisfaction And Its Implication Towards Employee Performance In Parador Hotels And Resort, Indonesia. International Journal Of Law Management, 59 (6), 1337-1358.

Pawirosumarto, S., Setyadi, A., \& Khumaedi, E. (2016). The influence of organizational culture on the performance ofemployees at University ofMercu Buana. International Journal of Law and Management Emerald Publishing Limited, 59 (6), 950-963.

Rahmisyari. (2015). Effect ofLeadership Styles, Organizational Culture, andEmployees Development onPerformance (Studies in PT. PG. Gorontalo of Tolangohula Unit). International Journal of Business and Management Invention, 4 (1), 85-91.

Razak, A., Sarpan, \& Ramlan. (2018). Effect Of Leadership Style, Motivation And Work Discipline On Employee Performance in PT. ABC Makasar. International Review Of Management And Marketing, 8 (6), 67-71.

Rivai, V. (2014). Manajemen Sumber Daya Manusia untuk Perusahaan, Edisi ke 6. Depok: PT. Raja Grafindo Persada.

Rivai, V., \& Sagala, E. J. (2011). Manajemen Sumber Daya Manusia Untuk Perusahaan dari Teori ke Praktik. Jakarta: PT. Raja Grafindo Persada.

Robbins, S. P., \& Judge, T. A. (2017). Perilaku Organisasi. Jakarta: Salemba Empat.

Robbins, S. P., \& Coulter, M. (2016). Manajemen. Jakarta: Erlangga.

Santoso, A. B. (2018). Pengaruh Disiplin Kerja, Motivasi Dan Budaya Organisasi Terhadap Kinerja Karyawan pada Panin Bank Cabang Pondok Indah. Jurnal Ilmiah KREATIF, 6 (1), 1-13.

Sanusi, A. (2011). Metodologi Penelitian Bisnis. Jakarta: Salemba Empat.

Saputra, T. A., \& Sembiring, J. (2017). The Influence of Organizational Culture, Job Satisfaction and Leadership Style on Employee Performance (Case Study in Online 
Travel Company Pojok Celebes Mandiri). International Journal of Science and Research, 6 (9), 1516-1522.

Sedarmayanti. (2011). Manajemen Sumber Daya Manusia Reformasi Birokrasi dan Manajemen Pegawai Negri Sipil. Bandung: PT Refika Aditama.

Septiarini, N. A., \& Gorda, E. S. (2018). Kecerdasan Intelektual, Kecerdasan Emosional, Kecerdasan Spiritual, Budaya Organisasi dan Kinerja Karyawan. Jurnal Manajemen dan Bisnis, 15 (4), 24-41.

Shodikin, A. (2018). Pengaruh Kepemimpinan Dan Budaya Kerja Terhadap Kinerja Tenaga Kependidikan Dengan Motivasi Kerja Sebagai Variabel Intervening (Studi Pada Universitas Islam Negeri Walisongo Semarang). Jurnal Penelitian Ekonomi dan Bisnis, 3 (2), 61-72.

Sinaga, R. O. (2017). Pengaruh Brand Image Terhadap Keputusan Pembelian Pada Cocorico Cafe \& Resto Bandung 2017. Proceeding of Applied Science, 3 (2), 258-264.

Sugiyono. (2013). Metode Penelitian Kuantitatif, Kualitatif, dan R\&D. Bandung: ALFABETA.

Sugiyono. (2014). Metode Penelitian Manajemen. Bandung: Alfabeta.

Sugiyono. (2016). Metodelogi Penelitian Kuantitatif, Kualitatif, dan R\&D. Bandung: ALFABETA.

Sulila, I., \& Naue. (2020). The Effect of Cultural and Working Discipline on Performance of Civil Apparatus. Public Policy and Administration Research, 10 (1), 17-23.

Suningsih, G. P., \& Ganawati, N. (2017). Pengaruh Budaya Organisasi, Motivasi Kerja, Disiplin Kerja Terhadap Kinerja Pegawai Di Bagian Keuangan Sekretariat Daerah Kabupaten Tabanan. Public Inspiration Jurnal Administrasi Public, 3 (1), 38-49.

Sunyoto, D. (2013). Teori, Kuisioner, dan Analisis Data Sumber Daya Manusia dalam Organisasi Sekolah. Yogyakarta: Multi Presindo.

Suryana, N., \& Wahab, A. A. (2020). The Effect of Work Discipline and Organizational Culture on Service Quality in Teaching and Learning Process (Case study of civil servant teachers in Kuningan Area). Advances in Social Science, Education and Humanities Research, 1 (10), 142-146.

Sutrisno, E. (2015). Manajemen Sumber Daya Manusia. Jakarta: Kencana Prenada Media Group.

Sutrisno, E. (2011). Manajemen Sumber Daya Manusia. Jakarta: Kencana.

Tanjung, R., \& Manalu, S. S. (2019). Pengaruh Disiplin Kerja, Kemampuan Kerja Dan Motivasi Kerja Terhadap Kinerja Karyawan PT Zurich Topas Life Batam. DIMENSI, $8,(2), 342-359$.

Wales, V., Mandey, L., \& Waenas, S. (2017). Pengaruh Budaya Organisasi, Gaya Kepemimpinan, Dan Disiplin Kerja Terhadap Kinerja Karyawan PT. Bank Tabungan Negara (Persero) TBK Kantor Cabang Manado. Jurnal EMBA, 5 (3), 4335-4444.

Wirawan. (2016). Budaya dan Iklim Organisasi Teori Aplikasi dan Penelitian. Jakarta: Salemba Empat. 